\title{
操縦微係数に及ぼナプロペラ, 舵の影響について
}

\author{
正員 湯 室 彰 規*
}

Influences of Propeller and Rudder on Maneuvering Stability Derivatives

by Akinori Yumuro, Member

Summary

A simple procedure for predicting stability derivatives of a ship equipped with a propeller and rudder from those for the bare hull was examined. A procedure of this kind is very important as it enables us to easily examine an influence of rudder area on stability derivatives and scale effect in maneuvering characteristics.

This paper indicates that the lateral force exerted by rudder deflection on a hull must be taken into consideration when making a presumption of this kind, and the influence of a propeller operating on stability derivatives is, in comparison with the influence of the rudder force, not so negligibly small that it cannot be disregarded. Further, through the above mentioned studying process, lateral force acting on the propeller installed on the obliquely moving ship was directly measured, and it was made clear that the force delivered to the propeller itself (the so-called fin effect of the propeller) would not be a significant component of the lateral forces produced by the action of the propeller on the hull and propeller.

\section{1 緒言}

操縱微係数を求めるためのいわゆる拘束模型試験で は, プロペラや舵の付加物の有無によっていくつかの状 態の試験が考光られる1),2)。船型間の操縦性能の比較検 討を行なら場合まず船体自身の特性を明確にし，これ 飞舵やプロペラの影響を付加するといら考方方は, 実用 的な意味に括いても有効なるのと考えられるが，従来， この試験をプロペラおよび舵を装備した場合と船体単独 の場合の 2 つの状態について実施し, かつこれらの結果 の間の関係について検討を加えた報告は意外に少ないよ うと思われる ${ }^{3), 4) 。 ~}$

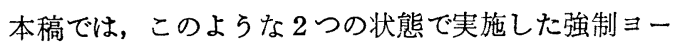
イング試験の結果の例を示し, この結果を基にして, 船 体単独の場合の砫係数からプロペラと舵を装備した場合

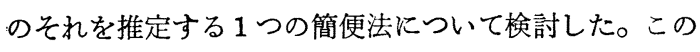
ような推定がある程度精度よく行なえれば, たと党ば舵 面積を変化させたとさ微係数がどのように変化するかと いう問題や尺度影響の問題などを考える上で非常に便利 であろう。また，この検討の過程において，従来あまり 調査されていない微係数に及ぼすプロペラの影響につい て考察するとともに，斜航する船体に取り付けられたプ ロペラ自身に作用する横方向の力を直接計测することを

* 石川島播磨重工業(株)技術研究所
試み、いくつかの計測例とその検討結果を示している。

\section{2 微係数に及ぼすプロぺラおよび 舵の影響の表示}

船の操緃運動によって舵やプロペラに力が発生する が，これらは船体自身の微俰数に含めて取り扱われる。 ここで述べる微係数に及洔す影響とはこれらの効果を意 味するるのとする。

プロペラおよび舵が作動しているときの操縱運動の方 程式として (1) 式の形の線形方程式を仮定する。この 式は, 舵による力として舵自身に作用する力のほかに操 舵によって船体に誘起される力5) を考慮し, また船の運 動が舵の力に与える影響のほかに, 船の運動によってプ ロペラに発生する力をる考虑したものである。

$$
\left.\begin{array}{c}
\left(M_{0}{ }^{\prime}+M_{y^{\prime}}{ }^{\prime}\right) \dot{\beta}+Y_{\beta^{\prime}} \cdot \beta-\left\{\left(M_{0}{ }^{\prime}+M_{x}{ }^{\prime}\right)\right. \\
\left.-Y_{r}\right\} r^{\prime}=Y_{1}{ }^{\prime}+Y_{2}{ }^{\prime} \\
\left(I_{z}{ }^{\prime}+J_{z}{ }^{\prime}\right) \dot{r}^{\prime}-N_{r} \cdot r^{\prime}-N_{\beta^{\prime}} \cdot \beta=N_{1}{ }^{\prime}+N_{2}{ }^{\prime}
\end{array}\right\}
$$

ここに

$$
\left.\begin{array}{rl}
Y_{1}^{\prime} & =k \frac{A_{r}}{L d}\left(\frac{\dot{V}_{r}}{V}\right)^{2} C_{\delta}\left\{\delta-C\left(\beta+\frac{l_{r}}{L} r^{\prime}\right)\right\} \cos \delta \\
Y_{2}{ }^{\prime} & =-\Delta Y_{\beta^{\prime}}\left(\beta+\frac{l_{p}}{L} r^{\prime}\right) \\
N_{1}{ }^{\prime} & =\frac{l_{r}}{L} Y_{1}{ }^{\prime} \\
N_{2}{ }^{\prime} & =\frac{l_{p}}{L} Y_{2}{ }^{\prime}
\end{array}\right\}
$$


ただし $\beta, \gamma^{\prime}, \delta:$ 横流れ角, 無次元回頭角速度並び 飞舵角

$k=Y_{\delta^{\prime}} / Y_{R \delta^{\prime}}\left(Y_{\delta^{\prime}}{ }^{\prime}\right.$ : 操舵によって舵拉よび船 体に生ずる力の微係数， $Y_{R \delta^{\prime}}$ : 舵自身に働 く力の微係数）

$A_{r}:$ 舵面積

$V, V_{r}:$ 船速拉よび舵への流入速度

$C_{\delta}:$ 舵の直圧力你数勾配

$l_{r}\left(l_{p}\right):$ 船の重心から舵軸（プロペラ位置）ま での距離

$C:$ 整流係数

$\Delta Y_{\beta^{\prime}}$ : プロペラの作動によって発生する横 方向の力の微保数

(1)式の右辺の第 1 項が舵によるもの，第 2 項がプロペ ラによるものであり，それぞれが（2）式のように表わ されるものとしている。

この式には次のような仮定が含まれている。 $C や \Delta Y_{\beta^{\prime}}$ は $\beta$ 拈よび $r^{\prime}$ の 2 変数の関数として取り扱らべきであ るが，ここでは便宜上船尾横流れ角を斜航角に等価とし て取り扱う。操舵によって船体唀起される力の作用点 の位置は，実際には船尾端より多少前方にあると考学ら れるが，ここでは，近似的に舵軸の位置にあるとして取

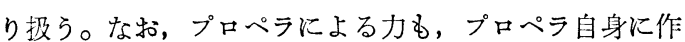
用するるのとそれの作動によって船体に発生するるのと から成っているが，簡単のためこれらを区別せず，後者 の力の作用点もプロペラ位置にあると仮定している。

船体単独の場合およびプロペラ，舵を装備した場合の 微係数に，それぞれ添字 0 拈よび p.r. を付すと，上述 した仮定のもとに（1)，(2) 式から次式が得られる。

第 1 表 模 型 船 の 要 目

\begin{tabular}{|c|c|c|c|c|c|c|}
\hline & 模型船 ( I ) & 模型船 ( II & 模型船 (III) & \multicolumn{3}{|c|}{ 模 型 船 (N) } \\
\hline$L_{p p}(=L) \quad(\mathrm{m})$ & 4.000 & 4. 000 & 3. 340 & \multicolumn{3}{|c|}{ 7.000 } \\
\hline$B \quad(\mathrm{~m})$ & 0.667 & 0.800 & 0.835 & \multicolumn{3}{|c|}{ 1. 167} \\
\hline $\begin{array}{ll}d & (\mathrm{~m})\end{array}$ & 0.253 & 0.266 & 0.223 & \multicolumn{3}{|c|}{0.443} \\
\hline$C_{b}$ & 0.83 & 0.80 & 0.75 & \multicolumn{3}{|c|}{0.83} \\
\hline & & & & 舵 No. 1 & 舵 No. 2 & 舵 No. 3 \\
\hline 舵面積比 $A_{r} / L d$ & $1 / 61.3$ & $1 / 49.5$ & $1 / 39.2$ & $1 / 45.0$ & $1 / 61.3$ & $1 / 80.0$ \\
\hline 綐横比 & 1.35 & 1.36 & 1.27 & 0.990 & 1.35 & 1.76 \\
\hline プロペラ直径 $(\mathrm{m})$ & 0.112 & 0.133 & 0.100 & \multicolumn{3}{|c|}{0.210} \\
\hline ピ口 千比 & 0.72 & 0.67 & 0.75 & \multicolumn{3}{|c|}{0.71} \\
\hline 翼 & 5 & 5 & 5 & \multicolumn{3}{|c|}{5} \\
\hline 回転方向 & 右 & 右 & 右 & \multicolumn{3}{|c|}{ 右 } \\
\hline 試験 船速 $F_{N}$ & 0.15 & 0.14 & 0.175 & \multicolumn{3}{|c|}{0.15} \\
\hline
\end{tabular}

$$
\left.\begin{array}{rl}
{\left[Y_{\beta^{\prime}}\right]_{\text {p.r. }}=} & {\left[Y_{\beta^{\prime}}\right]_{0}+k \frac{A_{r}}{L d}\left(\frac{V_{r}}{V}\right)^{2} C_{\delta} \cdot C+\Delta Y_{\beta^{\prime}}} \\
{\left[Y_{r^{\prime}}\right]_{\text {p.r. }}=} & {\left[Y_{r^{\prime}}\right]_{0}+k \frac{A_{r}}{L d}\left(\frac{V_{r}}{V}\right)^{2} C_{\delta} \cdot C \frac{l_{r}}{L}+\Delta Y_{\beta^{\prime}} \cdot \frac{l_{p}}{L}} \\
{\left[N_{\beta^{\prime}}\right]_{\text {p.r. }}=} & {\left[N_{\beta^{\prime}}\right]_{0}-k \frac{A_{r}}{L d}\left(\frac{V_{r}}{V}\right)^{2} C_{\delta} \cdot C \frac{l_{r}}{L}-\Delta Y_{\beta^{\prime}} \cdot \frac{l_{p}}{L}} \\
{\left[N_{r}^{\prime}\right]_{\text {p.r. }}=} & {\left[N_{r^{\prime}}\right]_{0}-k \frac{A_{r}}{L d}\left(\frac{V_{r}}{V}\right)^{2} C_{\delta} \cdot C\left(\frac{l_{r}}{L}\right)^{2}} \\
& -\Delta Y_{\beta^{\prime}} \cdot\left(\frac{l_{p}}{L}\right)^{2}
\end{array}\right\}
$$

ただし， $\cos \delta \fallingdotseq 1$ が成り立つと仮定している。従来の旋 回航跡などの操緃運動の推定計算に多く採られているさ らに簡単な取扱いによる場合は，（3)式に相当する表示 は（4）式のようになる。

$$
\begin{aligned}
& {\left[Y_{\beta^{\prime}}\right]_{\text {p.r. }}=\left[Y_{\beta^{\prime}}\right]_{0}+\frac{A_{r}}{L d}\left(\frac{V_{r}}{V}\right)^{2} C_{\delta} \cdot C} \\
& {\left[Y_{r}^{\prime}\right]_{\text {p.r. }}=\left[Y_{r}^{\prime}\right]_{0}+\frac{A_{r}}{L d}\left(\frac{V_{r}}{V}\right)^{2} C_{\delta} \cdot C \frac{l_{r}}{L}} \\
& {\left[N_{\beta^{\prime}}\right]_{\text {p.r. }}=\left[N_{\beta^{\prime}}\right]_{0}-\frac{A_{r}}{L d}\left(\frac{V_{r}}{V}\right)^{2} C_{\delta} \cdot C \frac{l_{r}}{L}} \\
& {\left[N_{r}^{\prime}\right]_{\text {p.r. }}=\left[N_{r}\right]_{0}-\frac{A_{r}}{L d}\left(\frac{V_{r}}{V}\right)^{2} C_{\delta} \cdot C\left(\frac{l_{r}}{L}\right)^{2}}
\end{aligned}
$$

以下，船体単独の場合からプロペラおよび舵のある場 合の微係数を推定するのに必要とする（3）または（4) 式中の各係数の值の評価を第 4, 5 章に, この結果を用 いて推定した微係数と実測值との比較を第 6 章において 述べることにする。

\section{3 模型船要目および試験状態}

まず，以下に示す試験データの模型船の要目などをこ こに述べておくことにする。第 1 表に要目を示す。いず れるタンカー船型である。さき に述べたように, 本稿では便宜 上一般の操粉運動を横流れ運動 のみに還元して取り扱うことが できると仮定しているので，第 4, 5 章については斜航試験のみ を行なっている。プロペラ回転 数は, 摩擦修正付きの直進自航 試験時のものと注淕等しい值 $\left(n_{0}\right)$ を基準とし，これを 1.5 倍 $\left(n / n_{0}=1.5\right)$ にしてプロペラ荷 重度を変化させた場合の結果も 若干示している。なお，自由に 航走する船では，斜航角（横流 れ角）が生ずると一般に船速が 低下してプロペラ荷重度も変化 するが，ここでは純粋に斜航角 の影響をみるために，以下の斜 

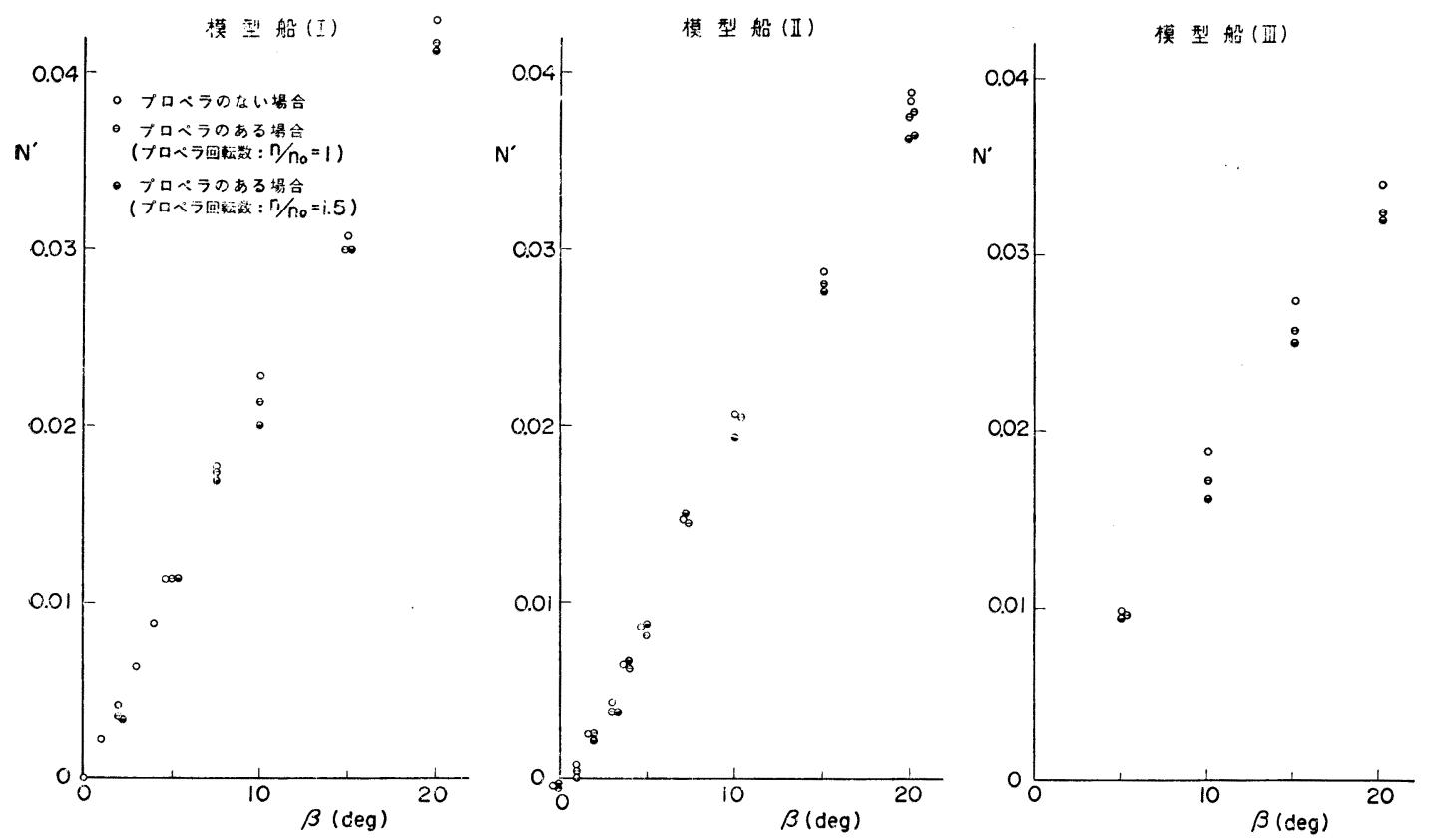

第1図 斜航モーメントに及ぼすプロペラの影響 (1)

航試験では斜航角を变化させる場合も船速，プロペラ回 転数は一定としている。

試験6)は上下動，縦摇れおよび横摇れの運動を自由に して行ない，船体横方向の力およびモーメントは，模型 船の重心の前後 2 箇所で計測される横力から求めてい る。検力素子は, 削り出しの門型フレームの中に差勳ト ランスを内蔵させた形式のものを使用している。

\section{4 微係数に及ぼすプロペラの影響}

\section{1 プロペラの存在によって発生する横方向の力}

プロペラが作動すると, 整流効果によってプロペラ自 身に横方向の力が発生するとともに, 船尾部の流れの状 態が変化するために船体に作用する流体力も変化する。 プロペラと舵との干渉の影響があるために, 舵が存在す る場合としない場合では，このような流体力も幾分異な るであろう。舵を船体から分離して船体の横力を計測す れば,この干渉の影響を含んだ值が得られるわけである が, ここでは計測の容易さから、この影響を無視して (3)式の $\Delta Y_{\beta}{ }^{\prime}$ を舵が存在しない場合の值で代用する。

舵を除き，プロペラのある状態とない状態で行なった 斜航試験の結果の例を第 1 図に示す。概して横力係数 $Y^{\prime}$ よりもモーメント係数 $N^{\prime}$ に打いて両者の状態の差 がより明瞭に現われるようであるので，ここでは $N^{\prime} に$ ついての結果を示している。るともと微少な量であるた めに, このよらな結果から $N^{\prime}$ の差 $\Delta N^{\prime}$ を正確に求め ることは元来困難なことであるが，大略の值を示すと第 2 図のようになる。

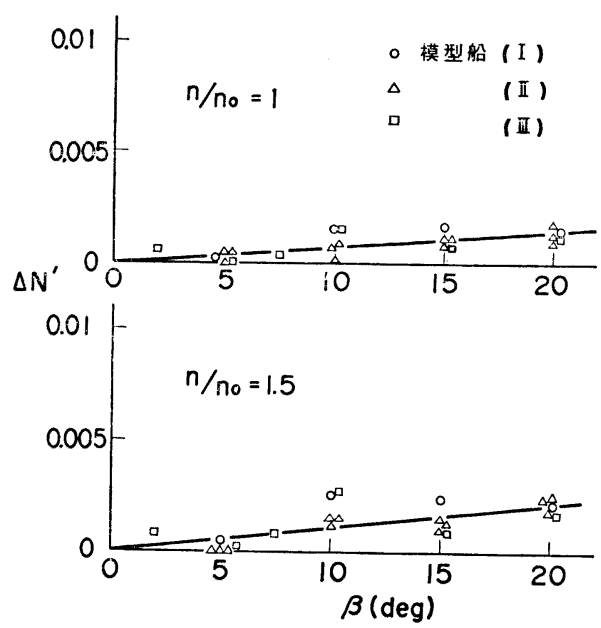

第 2 図 斜航モーメントに及ぽすプロペラの 影響 (2)

この図には，3 隻の模型船の結果を示しているが，船 型の影響について必ずしも一定の傾向が認められないこ と, 実験点のバラッキの大きさや再現性の点を考虑し て, 特に模型船の区別をせずにこれらの実験点の平均線 を記入している。ここで, $\Delta N^{\prime}$ は横流れ角 $\beta$ に対して一 応直線的に変化するすのと仮定している。 $Y^{\prime}$ の差 $\Delta Y^{\prime}$ は, $\Delta N^{\prime}=l_{p} / L \cdot \Delta Y^{\prime}$ の関係式を仮定することにして第 2 図から求めると, $\Delta Y_{\beta^{\prime}}$ の大略の值として 0.008 程 度の数値が得られる。2 軸船の場合の実験例が文献 4) に示されているが，大まかな見当として，1軸のタンカ 一船型の場合， $\Delta Y_{\beta^{\prime}}$ の值としてこの程度の量を見積っ 
ておけばよいと考えられる。

上述したように， $\Delta Y^{\prime}$ はプロペラ自身に生ずる力と船 体に誘起される力とから成っていると考えることができ るが，通常 fin 効果と称せられている前者の成分が実際 ぞの程度の大きさのものか, また $\Delta Y^{\prime}$ の中でどの程度 の割合を占めているかを次節において考察することにす る。

\section{2 プロペラ自身に働く横方向の力}

プロペラがー様流中を斜航する場合，すなわち open water test に対応する横方向の力の試騟例はこれまで にいくつかあるが7),8)，斜航する船体に取り付けられた プロペラに作用する横力を直接計測した資料はあまり多 く見られないように思われる。以下に，使用した計測装 置の概要, 計測結果の例および検討結果について述べる。

\subsection{1 計测装置の概要 ${ }^{9)}$}

使用した装置は，プロペラ朝上の 2 筒所に検力器を設 けて，それぞれで検出した力からプロペラ朝に直角方向 の横力を求める方式のもので, 軸方向のスラストも同時 に計測可能な 2 分力計となっている。製作するに当たっ て, 次の諸点に留意している。

（i）プロペラ軸を 2 箇所で支え，プロペラに作用す るモーメントを横力から分離して, 横力のみが梌出され るような構造にした。

(ii） プロペラ軸の変位を小さくしてスターン・チュ ーブとの間隍を極力小さくするために, 磁わい管型の祫 力器を採用した。

(iii） ユニバーサル・ジョイント部の軸中心間のずれ によるスラストの横力測定精度に及ぼす影響が大きいと 予想されるので, 本装置ではプロペラ軸とは別に切欠き を有する横方向に柔軟なスラスト伝達用の棒を設け，プ
ロペラ軸そのものにスラストを伝達させない機横にし た。

第 3 図に計测装置の概略図を示す。横力の較正につい ては, 直線性, 再現性ともに実用上問題ない程度の精度 が得られている9)。較正曲線がスラストやプロペラ回転 数の影響をほとんどうけないこと，またプロペラ軸とあ る角度をなす力向に荷重を作用させ，横力とスラストの 成分が正しく検出されていることを確認している9

\subsection{2 計測結果および検討}

計測されたプロペラ横力 $\left(1 / 2 \rho V^{2} L d\right.$ で除した無次元 值）を横流れ角 $\beta$ に対してプロットしたのが第 4 図であ る。ここでは $\beta=0^{\circ}$ のとさの值からの変化分を示してあ る。同図には，参考までに模型船（Ｉ）について舵のあ る場合とない場合の結果を示しているが，両者に大きな 差は認められない。このことは,プロペラ横力に関して いえば，舵との干渉の影響はほとんど無視してもよいこ とを示している。同図によると，この力は $\beta$ に対して必 ずしも直線的に変化せず, $\beta=15^{\circ}$ 近辺でピークが現われ るよらであるが，この傾向はスラストの変化の様子（第 5 図）に対応している。

プロペラ横力を推定するための計算式はいくつかある が，ここではスラストも同時に計測していることから， 一例としてスラストを用いて袁現した比較的簡単な式 ${ }^{10)}$

$$
Y_{p}=\frac{1}{2} \rho V_{p}^{2} F_{\frac{1}{\sqrt{\zeta_{s}}+1}} \beta_{p}
$$

ただし $V_{p}:$ プロペラ流入速度

$F:$ プロペラ円盤面積

$\zeta_{s}=S / \frac{1}{2} \rho V_{p}^{2} F(S:$ スラスト $)$

$\beta_{p}:$ プロペラ流入角
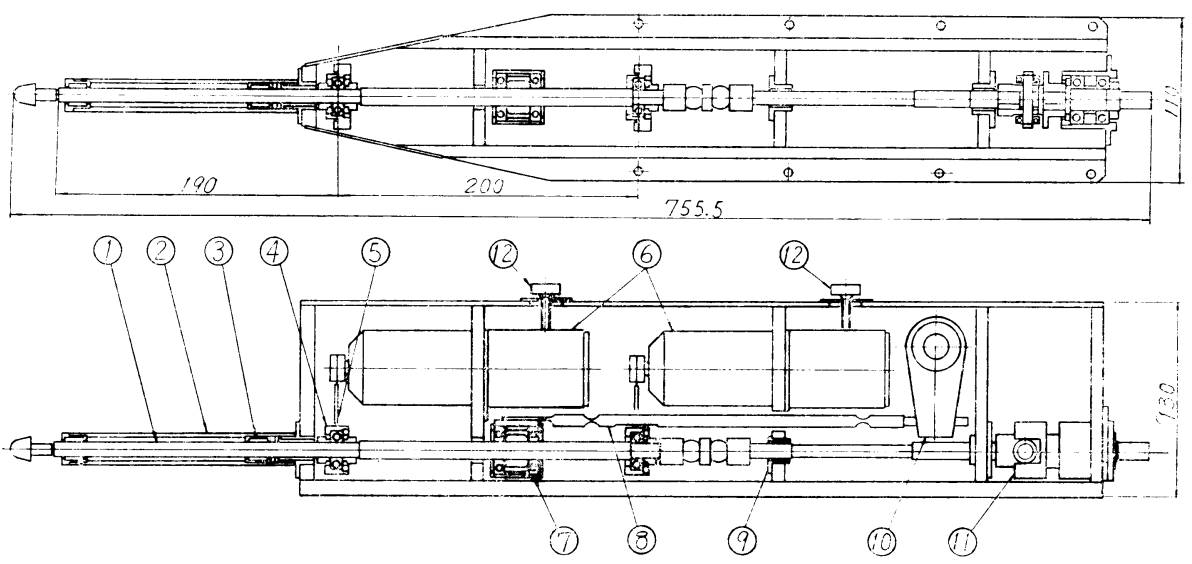

(1)プロペラ軸，(2)スタンチュープ，(3)リング(防水用)，(4)ハウジング(横力検出用)，(5)板ばね(横力伝達用)，(6横力榆出器(磁わい式)， (7)ハウジング(スラスト検出用)，(8スラスト伝達棒(直角 2 方向可橈), (9軸受, (10スラストレバー(スラスト伝達用), (11)スラストフリー カップリング(トルク佉達), (12検出器ロックネジ

第 3 図 プロペラ横力計測装置の概略図 
模型船 (I)

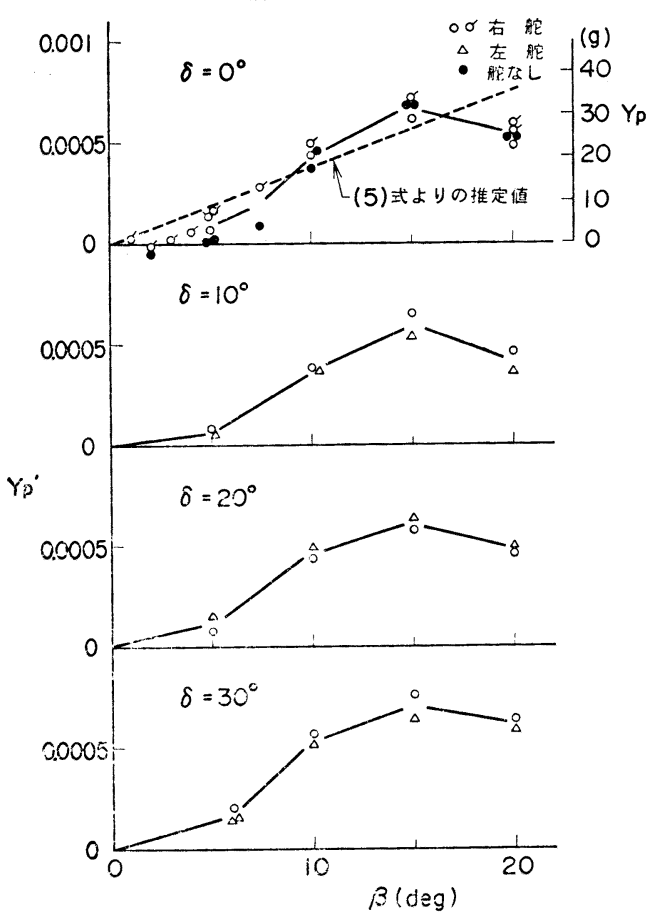

模型船 (II)

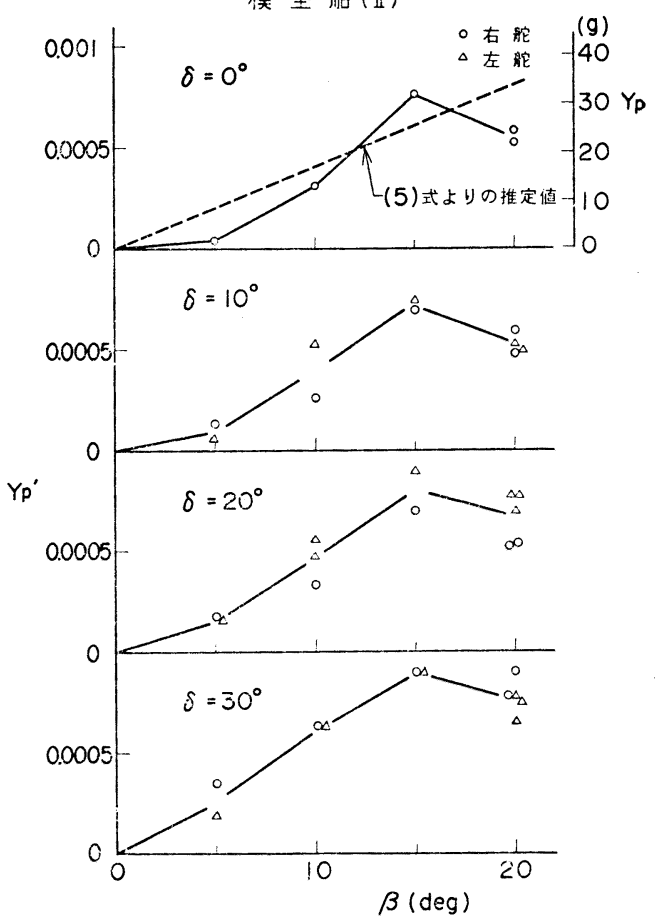

第 4 図プロペラに働く横力の䛨測結果
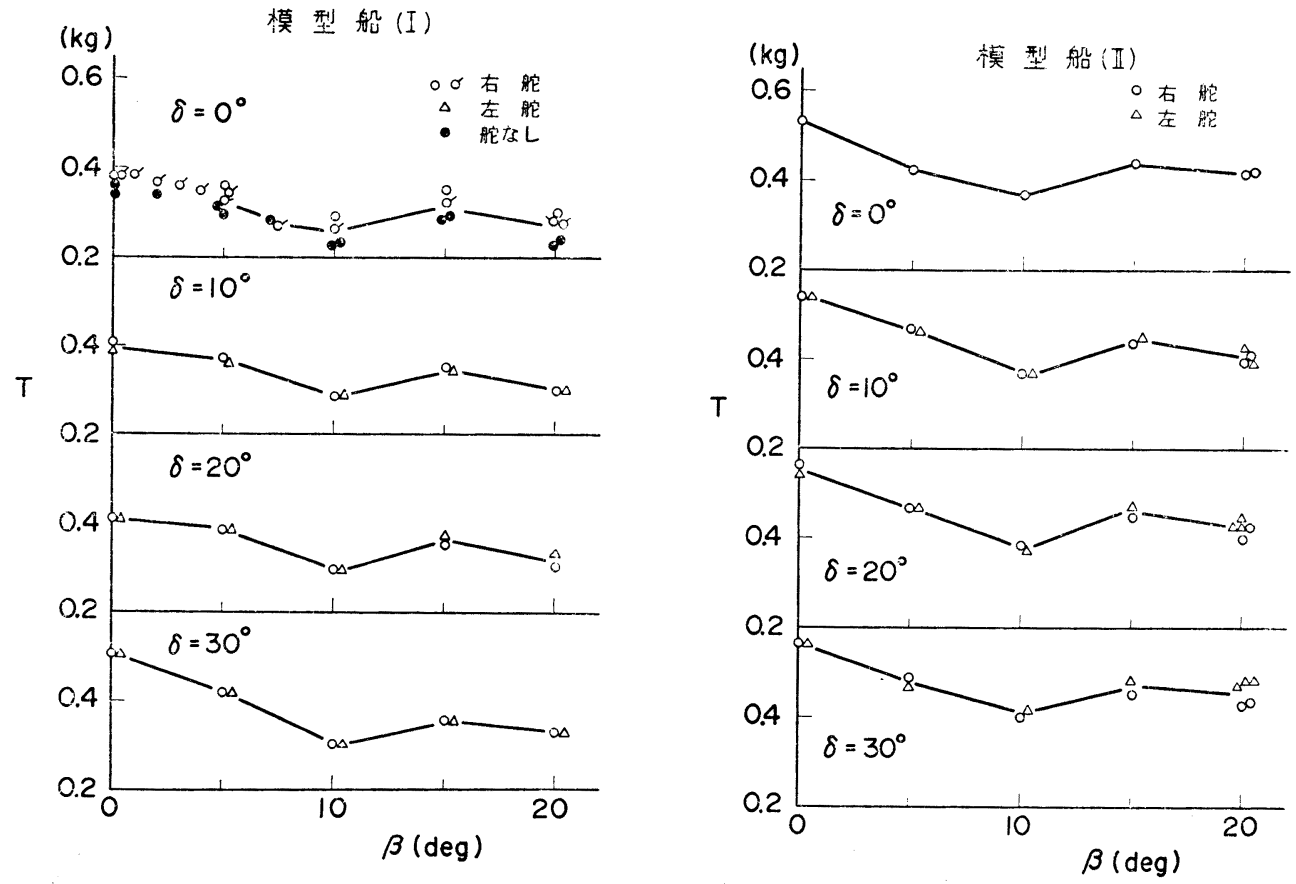

第 5 図プロペラ・スラストの計测結果 
による計算值を第 4 図に記入して計測値と比較した。こ こで，スラストの值として便宜上 $\beta=0^{\circ} に$ に拉ける実験值 を用いた。また，1- $w^{11)}$ および船体整流係数 ${ }^{12)}$ は第 2 表に示す数值を仮定した。以上の実験結果は, あるプロ ペラ回転数 $n / n_{0}=1$ の場合のもので, $\beta$ の符号も右旋回 の方向の限られた条件のもとでの結果であり, 今後さら にプロペラ荷重度や $\beta$ の方向の影響についても調査され なければならないが，第 4 図に見られるように，通常の プロペラ荷重度では斜航時の船体に取り付けられたプロ ペラに作用する横力は, 船体整流係数として第 2 表に示 す程度の適当な值を仮定すれば, 文献 10）の計算式で大 略推定できるものと考えられる。換言すれば, プロペラ に働く横力の大きさは, 文献 10）の計算式を使用する限 り，船体整流係数を 1 としたとさがその上限を与えると 考えてよい。

第 6 図に，さきに求めた $\Delta Y^{\prime}$ とプロペラに働く横力 の実測值 $Y_{p}^{\prime}$ との比較を示した。この結果から分かる ように, プロペラ自身に生ずる横力はプロペラが作動し たために発生する横力の一部であり，必ずしもそのほと んどを占めるものではないことがわかる。この図から $Y_{p}^{\prime}$ と $\Delta Y^{\prime}$ との拉拉よその割合を求めると, 前者は後者 の $20 \%$ 程度となる。この事柄をさらに確認する意味で, 文献 3)から第 3 表に示すような実験データを引用する。

第 2 表 プロペラ横力の推定に用いた 伴流係数および船体整流係数

\begin{tabular}{|c|c|c|c|}
\hline & & $1-w$ & C \\
\hline & 型 抬 (I) & 0.445 & 0.65 \\
\hline 模 & 型 船 (㔭) & 0.326 & 0.68 \\
\hline
\end{tabular}

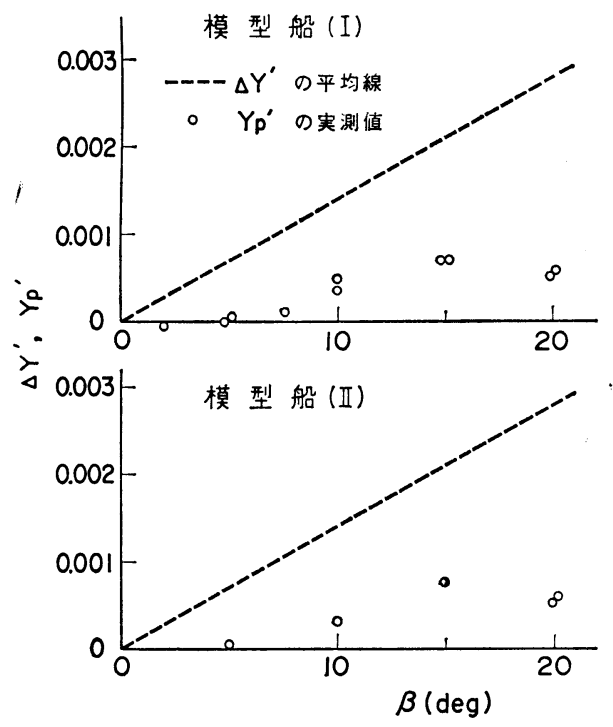

第 6 因 $Y_{p}^{\prime}$ が $\Delta Y^{\prime}$ K拈いて占める割合
第3表 $\Delta Y_{\beta^{\prime}}$ におけるプロペラ横力の 成分の例（文献 3）より）

\begin{tabular}{c|c}
\hline$\Delta \mathrm{Y}_{\beta^{\prime}}$ & $\mathrm{dY}_{\mathrm{P}}{ }^{\prime} / \mathrm{d} \beta$ \\
\hline 0.0266 & 0.00480 \\
\hline
\end{tabular}

捏 (1) $\mathrm{L} / \mathrm{B}=6.57 \quad \mathrm{C}_{\mathrm{b}}=0.842$

(2) $\Delta Y_{\beta}^{\prime}=Y_{\beta}^{\prime}\left(\right.$ 模型番号M 3 ) $-Y_{\beta}^{\prime}($ 模型番号M 1$)$

(3) $1-W=0.400$ と仮定 $(L=3.10 \mathrm{~m})$

模型番号 M 3 がブロペラ付きのもの, 模型番号 M 1 が 付かないもの (ともに舵は付いていない) で, $Y_{\beta}{ }^{\prime}(\mathrm{M} 3)$ $-Y_{\beta^{\prime}}(\mathrm{M} 1)=0.2624-0.2358=0.0266$ か $\Delta Y_{\beta^{\prime}}$ に相当 する。船型要素の類似した他船のデータから $1-w$ の值 を適当に推定し ${ }^{11)}$ ，同文献に掲げられているプロペラ特 性曲線からスラストを求め, (5) 式より $d Y_{p}^{\prime} / d \beta$ を算 出して $\Delta Y_{\beta^{\prime}}$ との割合を求める。ここでは一応船体整流 係数は 1 と仮定しているが，第 3 表に見られるようにこ の比は $20 \%$ 弱程度となり, 上述した本稿の実験結果と 同じ程度の値となる。

\section{5 微係数に及ぼす舵の影響}

\section{1 操舵によって船体に誘起されるカ} およびモーメント

（2）式の係数 $k$ の値については，これまで横流れ角 $\beta=0^{\circ}$ で舵角を変えた場合の実験はいくつかあるが5),13) 14)，ここでは比較的少ないと考えられる $\beta$ が $0^{\circ}$ でない 場合の実験結果について述べる。

よく知られているように補助翼をるつ 2 次元翼の計算 では, 揚力に対して主翼と補助翼の寄与は独立であり, また文献 15) のフラップ付き舵の実験結果でも，第 1 次 近似としてはフラップによる増加は主舵の舵角によらな いとされている。しかし, 船体と舵系の場合はフラップ 舵の場合に比して縦横比やプロペラの有無などの点で状 況が異なるので, このような独立性がフラップ舵の程度 に成り立っているかについては必ずしも明確ではない。

$\beta$ を変化させたときの $k$ の値の計測結果の例を第 7 図 に示す。 $k$ の值は, プロペラ, 舵を含めた船体に働く横 方向の力の舵角に対する勾配と舵に働く横方向の力のそ れとの比で定義されるが，ここでは後者の力が零となる 舵角の位置から $\pm 10^{\circ}$ の範囲の平均線の勾配を用いた。 実際には，操舵角によってプロペラ特性が変化するの で，第 7 図に示す $k$ の值も純粋に操舵のみの影響を示す ものではないが，ここではこの干渉の影響を無視して考 えていることになる。

本図によると $k$ の值に対する $\beta$ の影響の模様は模型船 （I ）（II）の 2 隻の模型船でよく似ており，1つの傾向 が現われているように思われる。また $k$ の值は $\beta$ に対し て比較的大きな変化を示しており, 取り扱い方の如何に 


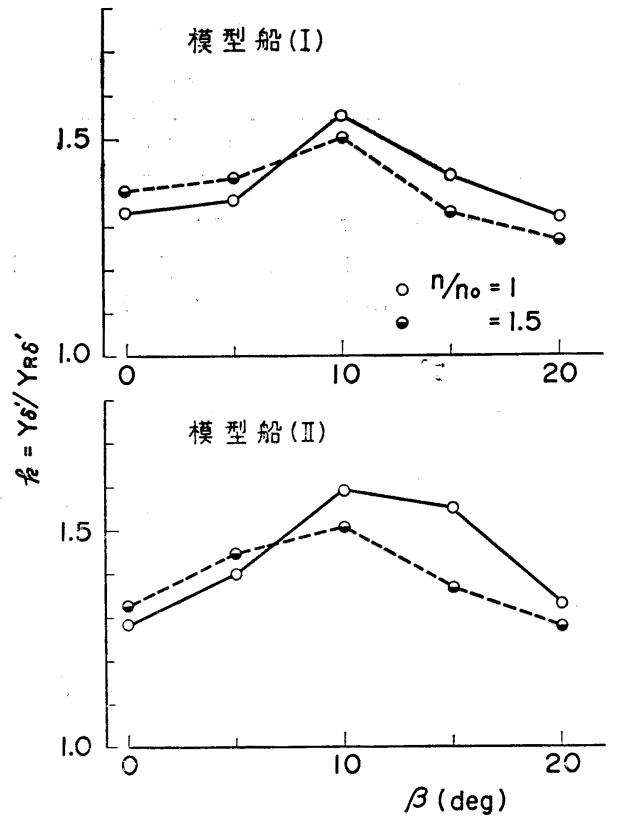

第 7 困 係数 $k$ と横流れ角との関係 （プロペラのある昜合）

よっては必ずしも $\beta$ に無関係に一定と見做せないように 思われる。この結果には, $\beta$ そのものの影響のほかに， それに伴らプロペラ特性の差異の影響が含まれていると 考えることがでさるので，比較のために第 8 四にプロペ ラを除いた場合の $k$ の実験結果を示した。これによる と, プロペラのない場合はある場合に比べて $\beta$ の影響は 小さく，第 7 図の $\beta$ に対する変化には斜流に伴らプロぺ ラ作動状態の変化の影響もかなり含まれていると考える ことができる。

次に操舵によって船体に誘起される横方向の力の作用
点の位置の計測結果について述べる。誘起される力およ び重心まわりのモーメントを $\Delta Y, \Delta N$ とし, 舵自身に 作用するそれらを $Y_{R}, N_{R}$ とすると，操舵による力お よびモーメントの増加率から

$$
\frac{\Delta N}{N_{R}} / \frac{\Delta Y}{Y_{R}}=\frac{\Delta Y \cdot l}{Y_{R} \cdot l_{r}} / \frac{\Delta Y}{Y_{R}}=\frac{l}{l_{r}}
$$

ただし $l$ :船の重心より $\Delta Y$ の着力点までの距離 の形で $\Delta Y$ の着力点の位置が求められる。 $l / l_{r}$ の計測 結果の一例を第 9 図に示す。文献 14) のシリーズ 60 の $C_{b}=0.7$ の船型の実験結果からは $l / l_{r}=0.679$ といら值 が得られるが, 本稿の結果でも $l / l_{r}=0.7 \sim 0.8$ 程度の值 が得られている。この結果によると, 本稿で対象として

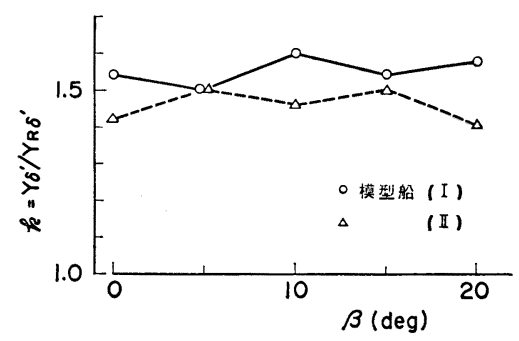

第 8 図倸数 $k$ と横流れ角との関係 (プロペラのない場合)

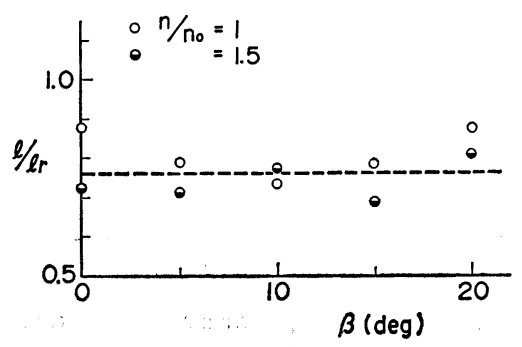

第 9 図操舵により船体に生ずる横力の 作用位置の例（模型船（I ））
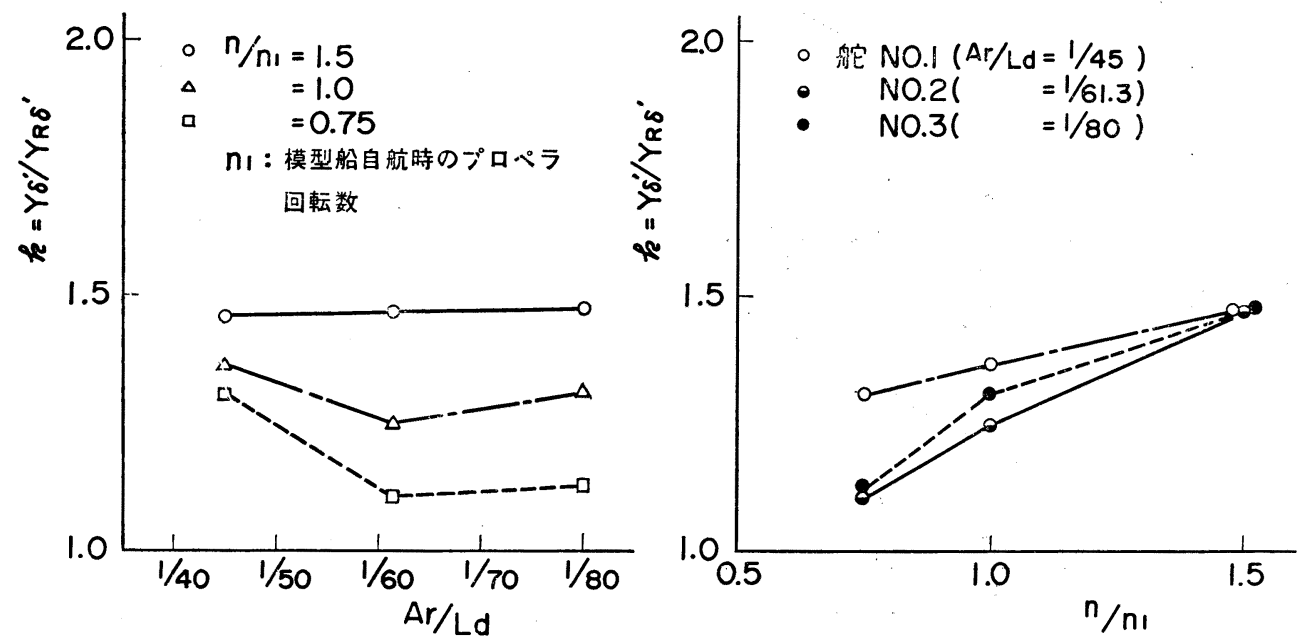

第 10 困係数 $k$ に及ぼす舵面積, プロベラ荷重度の影響の例（模型船 $(\mathrm{N})$ ) 
いるよらなタンカー船型の場合には, 着力点の位置はほ 注船尾近くにあると見做してよいといえる。前述したよ らに，(2)式の成立に怙いて着力点が舵軸位置にあると 仮定したが，本稿のような極く近似的な取り扱いに対し ては本質的な誤差の原因にはならないであるう。

模型船（I）と同船型でさらに大きい模型船（N) を 用いて, $k$ の值に及ぼす舵面積拉よびプロペラ荷重度の 影響について調査しているので, その結果を第 10 図に 示す。本図に見られるように，舵面積の影響については 必ずしも一定の傾向は認められないが，プロペラ荷重度 の影響については荷重度が大きくなるほど大きくなると いう性質が明瞭に䚋える。な㐾，本図の結果はさきに示 した模型船（I）のそれと絶対值そのものについては幾 分異なるが，実験条件が同一でないことや実験誤差を考 えに入れると，この差異が模型船の大きさの影響をその まま表わしているとはいえない。

\section{2 船尾プロペラ背後の舵の直圧力}

本稿では，(3)式の計算において船体背後の舵の直圧 力は与えられたものとして, 横流れ角 $\beta=0^{\circ}$ のときの実 測值をそのまま用いるものとする。したがって，今後微 係数に及ぼすプロペラ, 舵の影響を計算だけで求める場 合は，いずれかの方法で舵の直圧力を推定するという問 題が残されることになる。第 11 困に舵の直圧力の計測 結果の一例を示す。同図の $C_{N}$ は船の前進速度 $V$ で無 次元化したものであるので，(3) 式中の $\left(V_{r} / V\right)^{2} C_{\delta}$ の 值は

$$
\left(\frac{V_{r}}{V}\right)^{2} C_{\delta}=\frac{d C_{N}}{d \delta}
$$

の関倸によって同図のような $C_{N}$ 曲線の勾配をそのまま

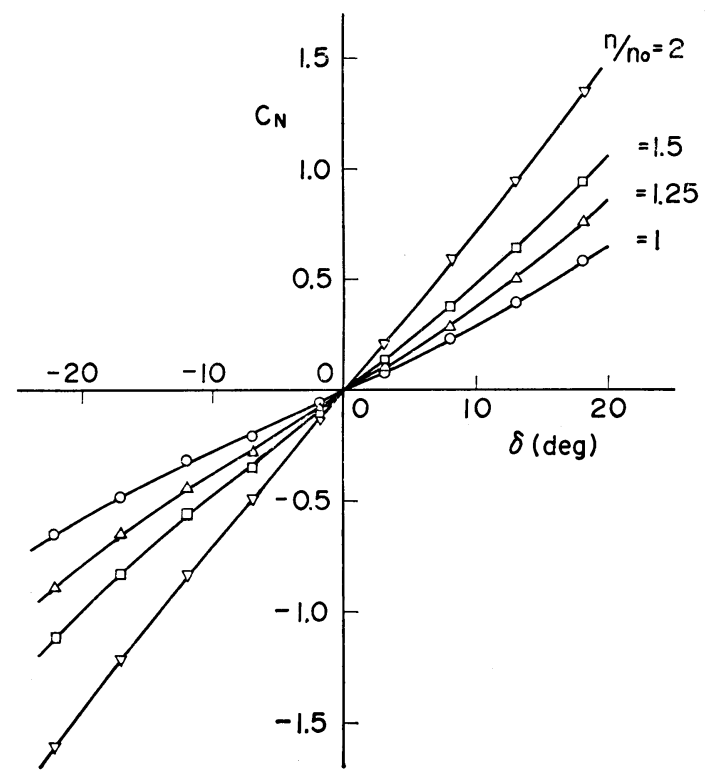

第 11 図 舵の直王力の計測結果の例（模型船(II)）
用いる。

\section{6 微係数の推定値と実測值との比較}

例として, 模型船 (I)，（II)の 2 つの模型船について， 船体単独の場合とプロペラおよび舵を付けた場合の $2 つ$ の状態で行なった強制ヨーイング試験の結果 (swaying の片振幅 $0.2 \mathrm{~m}$, プロペラ回転数 $n / n_{0}=1$ )を第 12 図に 示す。ここで, $M_{x}{ }^{\prime}$ を元良の図表 ${ }^{16)}$ から推定して $Y_{r^{\prime}}{ }^{\prime}$ 求めている。同図に拈いて, 前者の場合の実測值の平均 線を基にして第 4, 5 章で述べた諸データを用いて（3）, (4)式から推定したプロペラ, 舵のある場合の微係数と 実測値との比較を行なっている。計算に使用した数值を 第 4 表に示す。ここに示した試験結果は小振幅（pure swaying 時の横流れ角の片振幅は $2^{\circ} \sim 10^{\circ}$ 程度）で行な ったものであるので, 整流係数Cの值は 1.0 とした ${ }^{12)}$ 。 $\Delta Y_{\beta^{\prime}}$ の值は実際には船型やプロペラの種類によって異 なるであろらが，ここでは大略の值として船型により特 に区別をせず，第 2 図の平均線の一定値を用いた。 $k$ の 值も横流れ角 $\beta$ の関数として, たとえば平均的な $\beta$ に対 する值を用いればより合理的であるが，本稿では簡単な 取り报いを行なっている関係上 $\beta=0^{\circ}$ に怙ける值を使用 した。

第 12 図の比較によると,（3）式による推定値はほぼ 実測値を説明していること, (4)式による推定値は実测 值よりもかなり小さめの值を与えることがわかる。（3） 式に打ける第 3 項のプロペラの寄与は, 微係数の值の大 きさそのるのを問題にする場合は 2 次的であるので，こ の影響を考慮した場合としない場合の比較は省略してい るが，この寄与がより実測值に近くなる方向に作用する ことは第 12 図から明らかである。（3）式の第 2 項, 第 3項すなわち船体運動によって舵, プロペラに生ずる横 方向の力をそれぞれ仮りに舵力による成分，プロペラに よる成分と呼ぶことにして，それぞれの割合を評洒して みると第 5 表のようになる。同表によると，後者の成分 は前者のそれの大略 $20 \%$ 程度となっており, 微係数の 大ささそのものに与える影響は小さいにしても，前者の 成分との比率を考劣る限りでは無視できる程度の大きさ ではないと考えられる。

従来舵に働く力の計算に扰いては, プロペラの整流作 用による舵への流入角の減少の効果は考慮されていて む，それに伴って生ずるプロペラの横方向の力は無視さ れていた。以下に，さきに述べたデータに基づいて両者 の効果を算定して比較してみる。今, 簡単のため横流れ 運動のみを考劣ることにすると，流入角の減少による舵 直圧力の減少量は

$$
F_{R^{\prime}}=k \frac{A_{r}}{L d}\left(\frac{V_{r}}{V}\right)^{2} C_{\delta}(1-C) \beta
$$


模 型 船 (I)
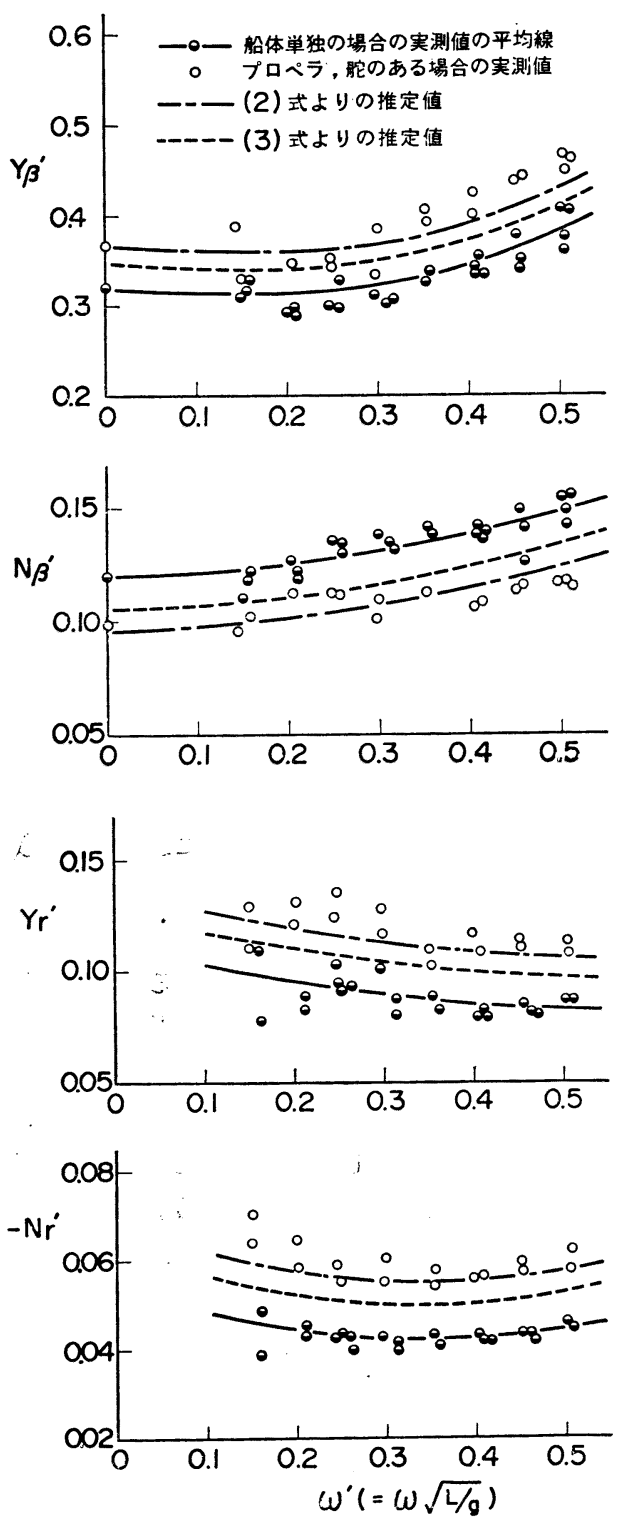

模 型 船 (II)
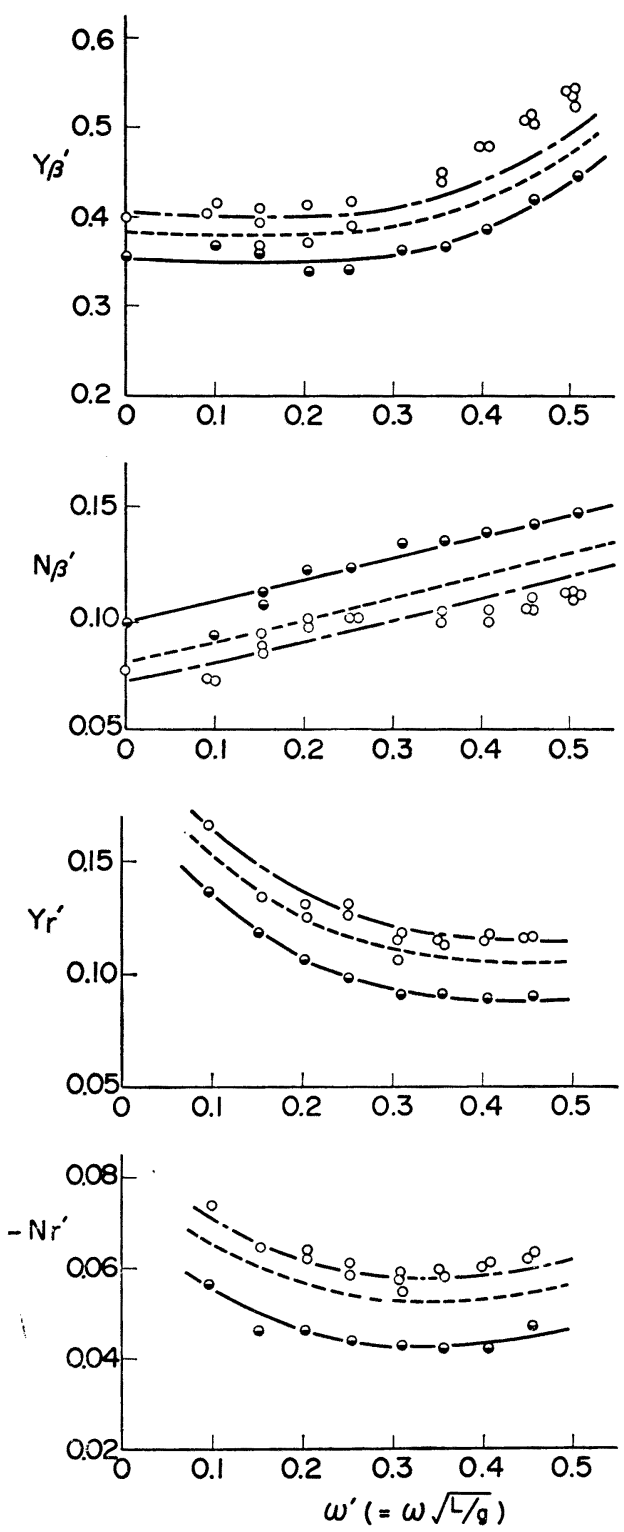

第 12 図微係数に及ぼすプロペラ, 舵の影響の推定值と実測值との比較

第 4 表 微倸数の推定計算に用いた数值

\begin{tabular}{|c|c|c|}
\hline & 模 型 船 (I) & 模 型 船 (II) \\
\hline $\operatorname{Ar} / L d$ & 0.016631 & 0.02020 \\
\hline $\mathrm{dc}_{\mathrm{N}} / \mathrm{d} \delta$ & 1.650 & 1.662 \\
\hline c & 1.0 & 1.0 \\
\hline$\Delta Y_{\beta}^{\prime}$ & 0.008 & 0.008 \\
\hline $\mathrm{k}$ & 1.33 & 1.28 \\
\hline
\end{tabular}

と表わされ，またプロペラに生ずる横力を 4.2 で述べた 記号を用いて

$$
F_{p}{ }^{\prime}=\frac{d Y_{p}^{\prime}}{d \beta}-\beta
$$

と表わすと，これらの割合は第 6 表のようになる。ただ し, この值は $\beta=10^{\circ}$ と仮定したときの值を使用してい る。この表によると, $F_{p}{ }^{\prime}$ は $F_{R}{ }^{\prime}$ よりる小さいが $F_{R}{ }^{\prime}$ のほぼ 60\% のオーダーとなっており, 両者の大きさの 比率を問題にする限り無視できる量ではない。 
第 5. a 表 微係数に及ぼすプロペラ, 舵の影響 の割合（模型船 $(I)$ )

\begin{tabular}{l|c|c|c}
\hline & 舵力に上万成分(1) & 舵力に上る成分(2) & ブロベラに上る成分 \\
\hline $\mathrm{Y}_{\beta}^{\prime}$ の補正量 & 0.0358 & 0.0269 & 0.008 \\
$\mathrm{Y}_{r^{\prime}}^{\prime} \mathrm{N}_{\beta}^{\prime}$ の補正量 & 0.0191 & 0.0144 & 0.00414 \\
$\mathrm{~N}_{r}^{\prime}$ の補正量 & 0.0102 & 0.00766 & 0.00214 \\
\hline
\end{tabular}

第 $5 . \mathrm{b}$ 表 微係数に及ぼすプロペラ, 舵の影響 の割合（模型船 (II))

\begin{tabular}{|c|c|c|c|}
\hline & 舵力に上る成分(1) & 舵力に上万成分(2) & ブロベラに上る成分 \\
\hline Y, ${ }_{g}^{\prime}$ 補正量 & 0.0430 & 0.0336 & 0.008 \\
\hline $\mathrm{Y}_{r^{\prime}, \mathrm{N}_{\beta}^{\prime}}$ の補正量 & 0.0234 & 0.0183 & 0.00422 \\
\hline $\mathrm{N}^{\prime}$ の補正最 & 0.0128 & 0.00997 & 0.00223 \\
\hline
\end{tabular}

牛舵力认上る成分 (1) : (2) 式の左边の第 2 项 舵力に上万成分 (2) : 网項におんて $\mathrm{k}=1$ とした㘯合 ブロベラル上る成分：同式の右边の第 3 項

第 6 表 プロベラの整流作用による横方向 力の変化量

\begin{tabular}{|c|c|c|}
\hline & 模 型 船 (I) & 模 型 船 (I) \\
\hline$Y_{\delta}^{\prime}(1-C)$ & 0.01253 & 0.0113775 \\
\hline$\left(Y_{R S^{\prime}}(1-C)\right)$ & $\left(\begin{array}{lllll}0.0 & 0 & 9 & 4 & 2\end{array}\right)$ & 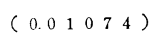 \\
\hline$\Delta Y_{\beta}^{\prime}$ & 0.008 & 0.008 \\
\hline$\left(d Y_{p}^{\prime} / d \beta\right)$ & 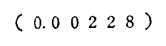 & $(0.00233)$ \\
\hline
\end{tabular}

\section{7 結 言}

タンカー船型を対象として操縦微係数に及活すプロぺ ラ，舵の影響に関連したいくつかの問題について検討し 大約次のような結果を得た。

1）船体単独の場合の微係数からプロペラおよび舵の ある場合のそれを推定する 1 つの簡便法について検討 し，このような推定の場合も，操舵によって船体に誘起 される力やプロペラの作動によって生ずる力を考慮する ことにより，より正しい值が得られるといら実験例を示 した。

2）船の運動によってプロペラに生ずる横方向の力 は, 舵に生ずる力と比べて, 微係数の大きさそのものに 与える影響としては 2 次的で小さいが，両者の大きさの 比率を考える限りでは必ずしも無視できる程度の大きさ ではない。

3）斜航する船体に取り付けられたプロペラに働く横 方向の力を直接計測することを試み，いくつかの計測結 果の例を示した。この力は, 船体による整流効果を適当 に仮定すれば文献 10）の計算式でほぼ推定できる。ま
た，プロペラ自身に働く力は，プロペラが微係数に及ぼ す影響の中で必ずしも主要な成分であるとは限らない。

4）従来, 舵力の計算に拈いて無視されていたプロペ ラの整流作用に基づくプロペラに働く横力（fin 効果） は, 同作用に基づく舵への流入角の減少による舵力の減 少量と比べて無視でさない程度の大きさとなる。

5）操舵によって船体に誘起される横力と舵に働くそ れとの比に及ぼす横流れ角, 舵面積, プロペラ荷重度の 影響の実験例を示した。この比は横流れ角 $\beta$ に対しても 比較的大きい変化を示すが， $\beta$ そのものの影響のほかに それに伴うプロペラ特性の差異の影響も大きいと考えら れる。

本稿を終えるに当たり，関連した問題をご討論いただ き，種々のご教示を賜わった試験水槽委員会第 2 部会の 操縱運動の数学モデル検討グループの諸先生方に厚く拉 礼申し上げます。また，日頃ご指導をいたたいている IHI 技術研究所の神中龍雄部長に感謝の意を表するとと もにここ援助をいたたいた田崎 亮部長はじめ試験水槽 の関係各位に厚くお礼申し上げます。

\section{参 考 文 献}

1）たとえば, S. Motora \& M. Fujino : On the Measurement of the Stability Derivatives by means of Forced Yawing Technique，造船協 会論文集，第 118 号 (昭 40.12).

2）たと㝑ば, H. Eda \& C. L. Crane : Steering Characteristics of Ships in Calm Water and Waves, SNAME Vol.73 (1965).

3) C.C. Glansdorp \& J.G. L. Pijfers : Effect of Design Modifications on the Natural Course Stability of Full Tanker Models, International Symposium on Directional Stability and Control of Bodies Moving in Water (1972).

4）柏谷達男 : 二軸船の船尾形状と進路安定性に関す る一資料，第 41 回試験水槽委員会第 2 部会資料， (昭 49.10).

5）鳥野慶一：操舵が船体に誘起する横方向の力につ いて，関西造船協会誌，第 133 号 (昭 44.9).

6）湯室彰規：幅広大型タンカー船型の操縱性に関す 万研究 (2), 石川島播磨技報, 第 15 巻, 第 5 号 (昭 50.9).

7）谷口 中, 渡辺恭二：推進器の斜流特性に関する 実験, 西部造船会々報, 第 8 号（昭 29.8）.

8）小陽弘，辻 豊治，森 政彦：斜航するプロべ ラに働く横力に関する研究，第 16 回船舶技術研 究所研究発表会講演概要 (昭 45.10).

9）湯室彰規：斜航するプロペラに働く横力に関する 実験例, 試験水槽委員会第 2 部会, 操縦運動の数 学モデル検討会第 6 回資料 (昭 51.10).

10) F. Horn : Querkräfte am Propeller bei Schräganströmung, speziell bei Manövriervorgängen, Schiffstechnik Heft 20 Band 4 (1957). 
11）湯室彰規：操緃性指数の縮率影響の一推定法, 日 本造船学会論文集, 第 137 号 (昭 50.6).

12）湯室彰規：斜航する船体の舵位㯰における流向に 関する実験的研究, 石川島播磨技報, 第 14 巻第 4 号（昭 49.7).

13）松本憲洋：旋回運動のシミュレーションについ て, 関西造船協会誌，第 150 号 (昭 48.9).

14）野本謙作, 鳥野慶一：新しい操縦性模型試験法,
日本造船学会論文集, 第 126 号 (昭 44.12).

15）加藤洋治, 元良誠三: フラップつき舵の研究（第 1 報: 単独試験の結果), 日本造船学会論文集, 第 124 号（昭 43.12）.

16）元良誠三：船体運動に対する付加質量および付加 モーメントについて(その 2), 造船協会論文集, 第 106 号 (昭 35.1). 